\title{
Does Sukuk financing boost economic growth? Empirical evidence from Southeast Asia
}

\author{
Mohammed Ayoub Ledhem \\ Department of Economics, University Centre of Maghnia, Maghnia, Algeria
}

\begin{abstract}
Purpose - This paper aims to investigate empirically whether Sukuk financing is boosting the economic growth in Southeast Asia within the framework of the endogenous growth model.

Design/methodology/approach - This paper applied dynamic panel one-step system generalized method of moments as an optimal estimation approach to investigate the impact of Sukuk financing on economic growth in Southeast Asia spanning from 2013Q4-2019Q3. Sukuk financing was proxied by the total issued Sukuk holdings, while economic growth was proxied by gross domestic product. The sample covered all full-fledged Islamic financial institutions in the most developed Sukuk financial markets countries in Southeast Asia (Malaysia, Indonesia and Brunei).

Findings - The findings demonstrated that Sukuk financing is boosting economic growth in Southeast Asia, which reflects the significant role of the Islamic financial markets of Sukuk as a vital contributor to economic growth.

Practical implications - This paper would fill the literature by investigating the link between Sukuk financing and economic growth in Southeast Asia within the framework of the endogenous growth model, as the outcome of this paper serves as a guide for financial researchers, decision-makers and policymakers to improve the Sukuk market globally as an alternative financing source for the best contribution to economic growth.

Originality/value - This paper is the first that investigates empirically the link between Sukuk financing and economic growth in Southeast Asia with a new theoretical context of the endogenous growth model to gain robust information about this link.
\end{abstract}

Keywords Economic growth, Dynamic panel one-step system GMM, Endogenous growth model, Islamic financial markets, Sukuk financing

Paper type Research paper

\section{Introduction}

Lately, Islamic finance turns out to be a major player in economic growth around the world, because of the expansion of its asset, it is predicted to grow to US $\$ 3.8 \mathrm{tn}$ by 2023 (Reuters, 2020). According to Lahsasna et al. (2018) and Al-Ali (2019), the main Islamic finance instrument that boosts economic growth currently is Sukuk. Sukuk are Islamic bonds certificates or Islamic debt securities that comply with Islamic laws where the profit from Sukuk is free from the interest, but it is derived from the performance of the underlying

(C) Mohammed Ayoub Ledhem. Published in PSU Research Review. Published by Emerald Publishing Limited. This article is published under the Creative Commons Attribution (CC BY 4.0) licence. Anyone may reproduce, distribute, translate and create derivative works of this article (for both commercial and non-commercial purposes), subject to full attribution to the original publication and authors. The full terms of this licence maybe seen at http://creativecommons.org/licences/by/4.0/ legalcode
Sukuk financing 
PRR

6,3

142

asset (Lahsasna et al., 2018; Al-Ali, 2019). Therefore, the profit produced from Sukuk is not interest-based, but it is consequent from the performance of the basic asset.

Lately, the Sukuk market has seen massive growth, particularly in the majority of Muslim economies. Hence, the most developed Sukuk markets in the world are in the southeast of Asia where the Islamic finance industry is developed in all of Malaysia, Indonesia and Brunei (Reuters, 2020). Malaysia remained dominant on the global Sukuk market by establishing $50.5 \%$ of the global Sukuk issuing, Malaysia maintained its ranking as the world's top issuer with a $41 \%$ of the total global Sukuk share in 2018's first half, a rise with 33\% a year earlier (IIFM Sukuk Report 2019 8th Edition, 2020). During 2018's first half, it released US\$22.4bn of Sukuk, an expansion of 9\% from the first half of 2017 (Figure. 1) (IIFM Sukuk Report 2019 8th Edition, 2020; Islamic Financial Services Board, 2020). This remarkable rise represented both an improvement in corporate issuance among a broad variety of industries and an increase in the number of short-term Islamic government bonds issued by Malaysia's central bank (IIFM Sukuk Report 2019 8th Edition, 2020).

Malaysia's domestic Sukuk market continues to function as a significant and lucrative forum for state and business companies to boost long-term funds for diverse economic, business and infrastructure growth requirements (IIFM Sukuk Report 2019 8th Edition, 2020). During 2018's first half, government and corporate Sukuk issuances contributed to RM99.36bn, comprising $52.02 \%$ of the overall bond issue, relative to RM79.01bn in the first half of 2017, while total issued Sukuk outstanding rose to RM818.41bn, or $59.59 \%$ of overall issued debt, relative to RM718.41bn in the first half of 2017 (IIFM Sukuk Report 2019 8th Edition, 2020). This enormous Sukuk development reflects why Malaysia is the top pioneer country in Islamic finance with the best Global Islamic Economy Indicator (GIEI) score of 111, which reflects the best Islamic finance performance in the world (Reuters, 2020).

Similar to the path of Malaysian Islamic finance, Indonesia witnessed a remarkable development in the Islamic finance industry and Sukuk markets. Despite a competitive climate, the Indonesian Sukuk market displayed steady growth in 2018. Specific foreign problems guided slower global economic growth, which effected Islamic financial markets in Indonesia. Nevertheless, both the Indonesian government and the Sukuk companies remained in a good position with sustained development at issuing Sukuk in 2018. In the first half of 2018, both the Indonesian government and the Sukuk companies released US $\$ 2.472 \mathrm{bn}$ of Sukuk, an expansion of $37.13 \%$ from the first half of 2017 (Islamic

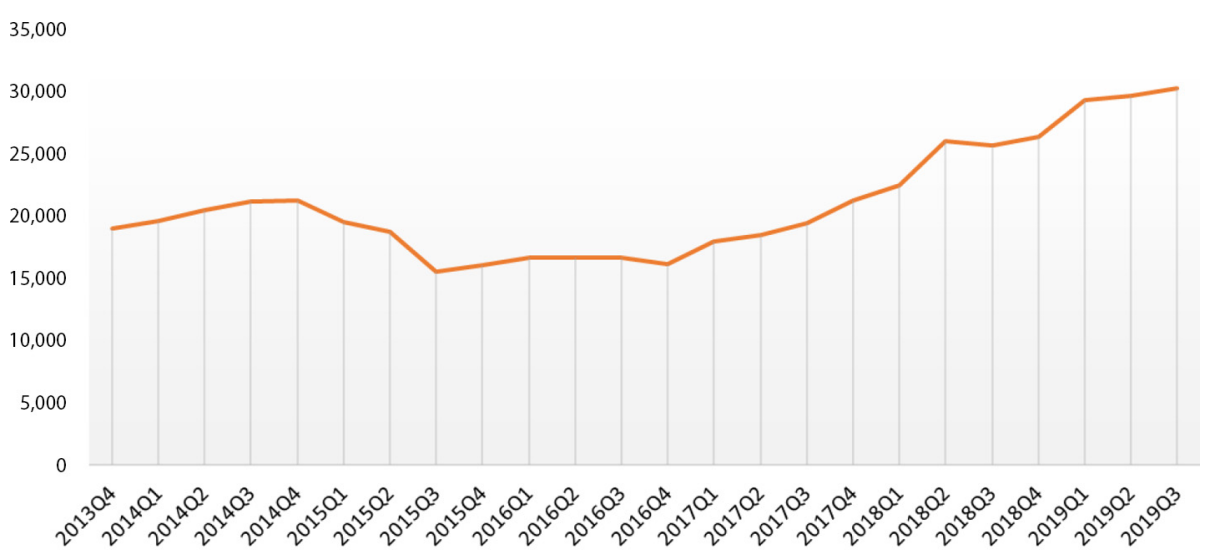

Source: Prepared graph from the Islamic financial services board (IFSB) database

Figure 1.

Sukuk finance holdings development in Malaysia (US\$m) 
Financial Services Board, 2020) (Figure. 2). This immense Sukuk development mirrors why Indonesia placed globally the fifth country in Islamic finance performance with a GIEI score of 49 (Reuters, 2020).

Following the path of the developed Sukuk markets in Malaysia and Indonesia, Brunei is extraordinary underground for the Islamic finance industry and Sukuk markets. Brunei tends to dominate the global sector in Sukuk with a growing number of issuances focused mainly on financing infrastructure projects since The Brunei Darussalam Government, via its representative, Autoriti Monetari Brunei Darussalam (AMBD), released its 164th Sukuk series which are valued BND50m (IIFM Sukuk Report 2019 8th Edition, 2020). Through this issue, the Brunei government had released short-term Sukuk Al-Ijarah securities valued more than BND12.41bn after its first bid on April 06, 2006 (IIFM Sukuk Report 2019 8th Edition, 2020). During 2018's first half, both the AMBD and the Sukuk financial corporations released US $\$ 173.0380 \mathrm{~m}$ of Sukuk, an expansion of $19.32 \%$ from the first half of 2017 (Islamic Financial Services Board, 2020) (Figure. 3). This vast Sukuk development reflects why Brunei placed internationally the tenth country in Islamic finance performance with a GIEI score of 40 (Reuters, 2020).

According to Haini (2019), Southeast Asia witnessed enormous economic growth lately due to development in the financial markets, and because the Sukuk markets are a part in the financial markets, this brings a debate whether Sukuk (Islamic bonds) financing is promoting either the economic growth in Southeast Asia. For this reason and as an expansion to the literature on investigating the link between Sukuk financing and economic growth, this study aims to investigate whether Sukuk financing is promoting economic growth in Southeast Asia.

Based on the research of Echchabi et al. (2018), pure studies that investigated the link between Sukuk financing and economic growth are limited; consequently, there is an understanding lack of this link. Thus, this study is enriching the literature by giving more pure investigation on this link from a robust sample of the Southeast of Asia, which contains remarkable Islamic financial markets. Currently, Southeast Asia witnessed a speed rise in capital stock, investments and knowledge accumulation, which led to a quick economic growth reliably with the context of endogenous growth theory (Canlas, 2020). Therefore, this paper is providing a significant contribution to the literature by investigating empirically the link between Sukuk financing and economic growth based on a new theoretical context

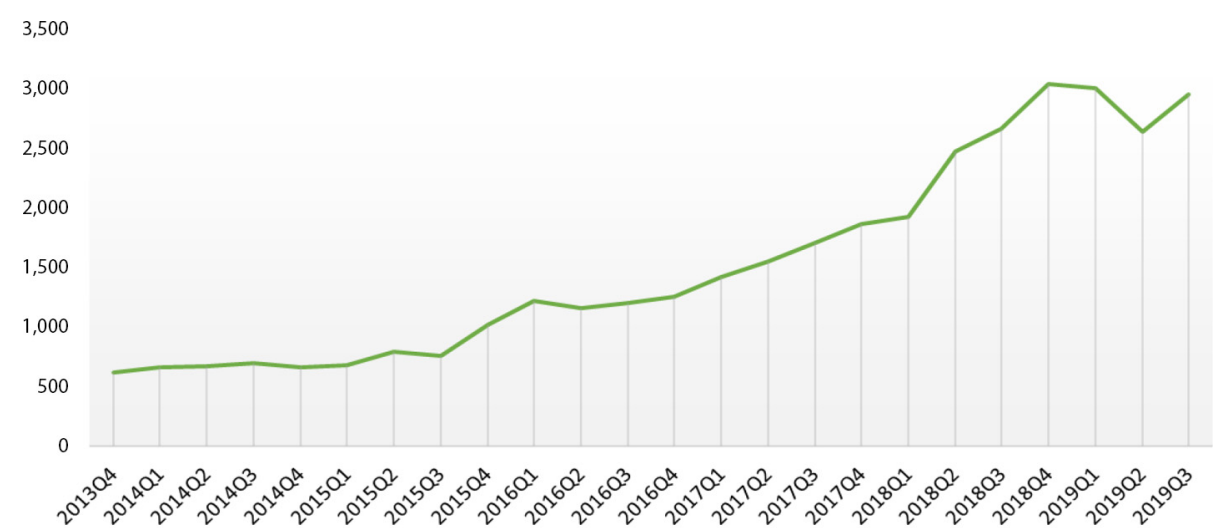

Source: Prepared graph from the Islamic financial services board (IFSB) database

Figure 2.

Sukuk finance development holdings in Indonesia 

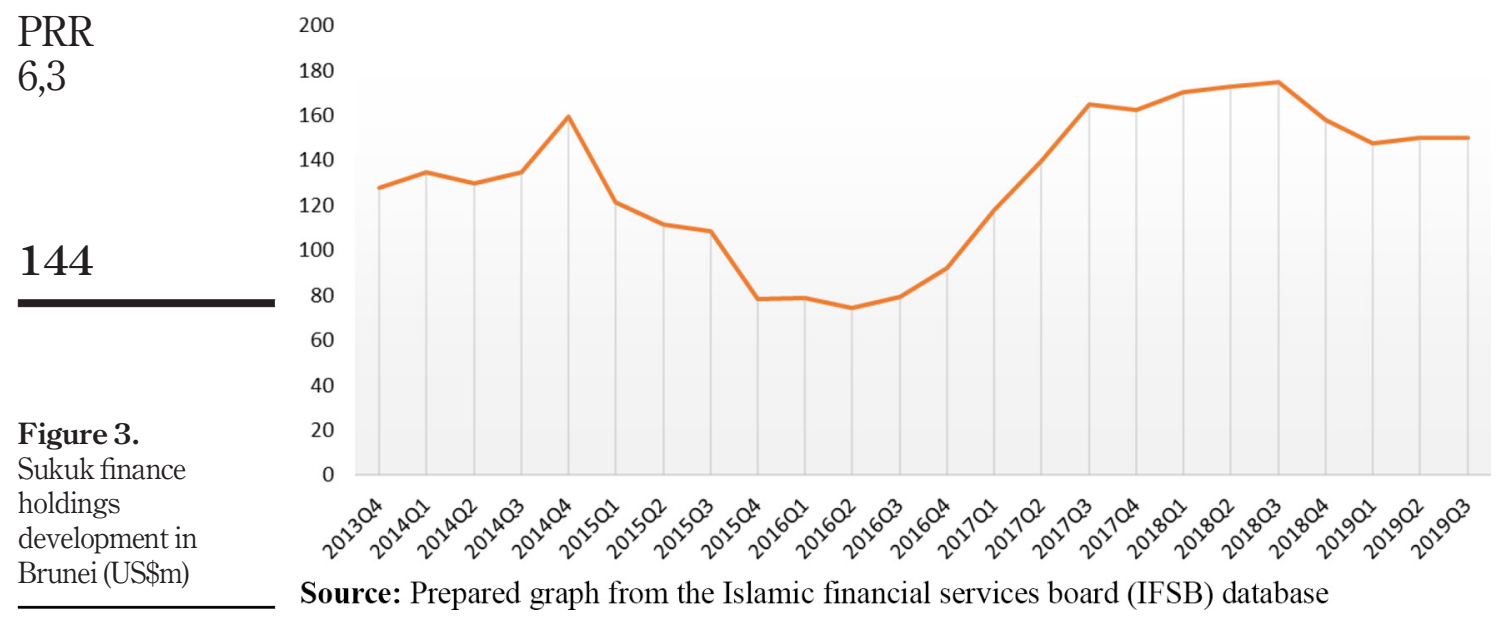

Source: Prepared graph from the Islamic financial services board (IFSB) database

within the framework of the endogenous growth model in Southeast Asia throughout Malaysia, Indonesia and Brunei as the top pioneer countries at issuing Sukuk. Thus, this paper answers the following question: "Does Sukuk financing boost economic growth in Southeast Asia?"

According to Haini (2019), financial markets development are enhancing economic growth in Southeast Asia. As the Islamic financial markets of Sukuk (Islamic bonds) are part of the financial markets and for the reason that Sukuk markets enhance economic growth internationally, this paper formulates the hypothesis as the following:

H1. Sukuk financing affects positively the economic growth in Southeast Asia.

\section{Literature review}

Sukuk financing and economic growth background within the endogenous growth model

Based on the supply-leading hypothesis of Schumpeter identifications (Schumpeter and Redvers, 1934), the economic theory determined that finance is promoting economic growth, this perception is also compatible with the financial repression theory of McKinnon (1973) and Shaw (1973), in which the financial markets and financial channels of investments can boost economic growth. As an expansion for those classical theories, the endogenous growth theory (Romer's theory) is assuming that economic growth is affected by exogenous factors like financial markets within the economic growth model (Romer, 2011) due to the growth of investments and human capital stock size (Jhingan, 2011). The are many notable empirical studies confirming that financial markets of securities are exogenous factors inside the endogenous growth model, Bencivenga and Smith (1991) determined that financial intermediation stimulated the loans that can finance the long-term investments because of the rise of deposits and capital stock, which leads to economic growth based on the endogenous growth model. Similarly, Saint-Paul (1992) demonstrated that financial markets are promoting entrepreneurship technological specialization that leads to economic development. Besides, Blackburn and Hung (1998) determined that financial development and trade liberalization could boost the development of intermediation, which boosts economic growth. Also, King and Levine (1993), Levine and Zervos (1998), Rajan and Zingales (1996) and Hassan et al. (2011) indicated that finance development and financial 
markets of securities promoted economic growth from increasing innovation, which leads to high productivity and is thus important for economic growth based on the endogenous growth model. Besides, the notable empirical studies of Fink et al. (2003), Thumrongvit et al. (2013), Kapingura and Makhetha-Kosi (2014), Pradhan et al. (2015), Fanta and Makina (2017) proved that financial markets of securities boosted economic growth through stimulating investments and capital stock. Consequently, securities development is boosting economic growth according to the endogenous growth model.

As Sukuk are a type of securities in the financial markets, many notable studies of Echchabi et al. (2016), Malikov (2017), Mitsaliyandito et al. (2017), Smaoui and Nechi (2017), Echchabi et al. (2018) and Sari et al. (2018) determined that Sukuk development is promoting economic growth by rising investments and capital stock. Consequently, based on the endogenous growth model, when investments and the capital stock is raised by Sukuk, Sukuk is an exogenous factor that affects economic growth positively. Besides, according to Ledhem and Mekidiche (2020), Islamic finance is boosting economic growth globally as an exogenous factor within the endogenous growth model. Thus, as Sukuk is a part of the global Islamic finance that boosts endogenous economic growth, it is better to conclude also that Sukuk is an exogenous factor that boosts economic growth within the endogenous economic growth.

\section{Previous empirical studies}

Many studies determined that Islamic finance is boosting economic growth (Kassim, 2016; Boukhatem and Moussa, 2018; Ledhem and Mekidiche, 2020). However, pure studies of the link between Sukuk and economic growth are limited. For this reason, and as an extension to the studies on Sukuk and economic growth, this study examines the relationship between Sukuk financing and economic growth in the framework of the endogenous growth model, and it investigates empirically the effect of Sukuk financing as an exogenous factor of economic growth within the endogenous growth model. Therefore, this paper is the first that addresses the investigation of the link between Sukuk financing and economic growth in the framework of the endogenous growth model. Consequently, it is believed that this paper will add a significant contribution to the literature.

In a recent study, Y1ldırım et al. (2020) measured the effect of Sukuk market development on economic growth through a simple of nine countries that have Islamic banking and finance over periods from 2014Q1-2017Q4. They used panel cointegration regression with a dependent variable of the gross domestic product as a measure for economic growth. Concerning independent variables, total Sukuk export was used as a measure for the Sukuk market, Sukuk density as a measure for Sukuk market development. Regarding control variables, trade, inflation and financial stress were used as control variables. They determined the existence of a long-term cointegration link between Sukuk market development and economic growth when Sukuk density and Sukuk export have a positive effect on economic growth.

Similarly, Al-Raeai et al. (2018) investigated the impact of macroeconomic factors on Sukuk market development in the gulf cooperation council spanning the period 2001-2016 to propose the Sukuk as an alternative financing source. They concluded that Sukuk market development can boost economic growth.

In the same context, Sari et al. (2018) examined the impact of three Islamic capital markets of Sukuk on economic growth in Indonesia covering a period from January 2011 to December 2017. They used the co-integration regression to investigate the existence of a long-term relationship between the Islamic capital market of Sukuk and economic growth. 
PRR

6,3

Their results indicated that the Islamic capital market of Sukuk is boosting economic growth in the long term to be an alternative financial instrument in Indonesia.

In a similar study, Malikov (2017) explored the effect of sovereign Sukuk issuances on economic growth in Saudi Arabia and Malaysia. He used statistical analysis to test the significant impact of sovereign Sukuk issuances on economic growth proxied by GDP. His results showed that sovereign Sukuk issuances had a positive effect on economic growth in Saudi Arabia and Malaysia.

In a more recent study, Mitsaliyandito et al. (2017) examined the effect of Sukuk market developments on economic growth in Indonesia spanning the period 2009-2016. They used vector autoregression (VAR) and Granger causality to test the impact of Sukuk market developments on economic growth. The outstanding Sukuk was used as an independent variable for the size of Sukuk markets, gross domestic product was used as dependent variables. Their results exposed that the economic growth in Indonesia was affected positively by the domestic sovereign Sukuk market.

Further, Smaoui and Nechi (2017) investigated the effect of Sukuk financial market development on economic growth using a sample of all Sukuk-exporting countries covering the period 1995-2015. They applied system generalized method of moments (GMM) for the empirical investigation. Sukuk market development was proxied by two factors, the ratio of Sukuk market capitalization and the total issued Sukuk. They determined that the Sukuk market development boosted economic growth.

On the other hand, Khoutem (2014) explored the role of the link between Islamic banks and Sukuk markets on economic growth in Tunisia after the 2011 Tunisian revolution. Their findings revealed that the Islamic intermediation improved the Sukuk markets, which can boost economic growth in Tunisia.

In another special case, Echchabi et al. (2018) investigated the impact of Sukuk issuance on the economic growth for GCC countries spanning a period from 2005-2012. They used the of the gross domestic product as a dependent variable for economic growth, Sukuk issuance as the main independent variable, trade activities and gross capital formation as control variables. They used Toda and Yamamoto analysis. They indicated that Sukuk financing did not affect economic growth.

Further, Echchabi et al. (2016) explored the impact of Sukuk issuance on the economic growth for the major Sukuk-issuing countries covering a period range from 2005-2012. They used Toda and Yamamoto approach to estimate the impact of Sukuk issuance as the main independent variable, trade activities and gross capital formation as control variables on the gross domestic product as a dependent variable for economic growth. They demonstrated that Sukuk issuing did not affect economic growth.

According to the literature, this study used the most appropriate empirical model and the most suitable variables for investigating the role of Sukuk financing on economic growth in Southeast Asia. Furthermore, unlike the previous studies, this research would fill the literature gap by investigating the link between Sukuk financing and economic growth in a framework of the endogenous growth model. Therefore, this is the first study that investigates the link between Sukuk financing and economic growth with this theoretical framework. Hence, it is believed that this paper will make a significant contribution to the literature.

\section{Research methodology \\ Sample and data collection}

This paper used a balanced panel data of all full-fledged Islamic financial institutions working in three major Sukuk-issuing countries of Southeast Asia (Malaysia, Brunei and 
Indonesia) spanning from the last quarter of 2013 to the third quarter of 2019 (2013Q42019Q3). The Sukuk financing data were drawn from quarterly datasets of the Islamic Financial Services Board (IFSB) database. Other macroeconomic data were collected from Bank Negara Malaysia, the Brunei Ministry of Finance, Economy the Indonesian Central Bank and the IMF database. As all countries (Malaysia, Indonesia and Brunei) have diverse currencies, all the quarter financial values were transformed in the US dollars by appropriate average exchange rates from the International Monetary Fund (IMF) database for each quarter.

\section{Experimental variables}

Sukuk financing variable. Following Smaoui and Nechi (2017), Echchabi et al. (2018), Yildırım et al. (2020), the Sukuk financing variable (Sukuk) is determined with total issued Sukuk holdings in all of Malaysia, Indonesia and Brunei.

The economic growth variable. All reviews in this paper settled on the use of the gross domestic product (GDP) as a proxy for economic growth when it is analyzed with the Sukuk and Islamic finance. Thus, this paper used the GDP as a dependent variable for economic growth (Echchabi et al., 2016; Malikov, 2017; Smaoui and Nechi, 2017; Al-Raeai et al., 2018; Echchabi et al., 2018; Yildirım et al., 2020).

Macroeconomics variables. To avoid the problem of bias due to omitted macroeconomic variables, other variables were included in the estimated model to show the potential effects of other determinants of economic growth, which were used based on the previous studies relating to the link between Sukuk and economic growth and also based on the link between Islamic finance and economic growth, trade openness (Trade) (Smaoui and Nechi, 2017; AlRaeai et al., 2018; Boukhatem and Moussa, 2018; Yıldırım et al., 2020; Ledhem and Mekidiche, 2020), gross fixed capital formation (GFCF) as a proxy for investments (Kassim, 2016; Ledhem and Mekidiche, 2020) and consumer price index (CPI) as a proxied factor of inflation (Kassim, 2016; Setyawati et al., 2017; Smaoui and Nechi, 2017; Ledhem and Mekidiche, 2020; Y1ldırım et al., 2020).

Therefore, the estimation variables are:

- Dependent variable: GDP.

- Independent variables: Sukuk.

- Control variables: GFCF, Trade and CPI.

\section{Estimating model}

According to the literature review, most studies have settled to adopt panel regression models such as panel GMM, panel regression (fixed and random effects). Thus, this paper applied dynamic panel one-step system GMM as an optimal estimation method after checking the invalidity of both panel with fixed effects, and panel with random effects for estimation due to the autocorrelation in panel data and the existence of panel heteroskedasticity problem. Besides, according to Hayakawa (2007) and Soto (2009), the dynamic panel system GMM estimator is the best method for small and finite samples. Thus, as this study has a small sample (72 observations), it is suitable to perform the dynamic one-step panel system GMM for robust unbiased estimated results.

The basic problem in the empirical examination of economic growth is the including of the most suitable control variables within the model. Brock and Durlauf (2001) described this problem of including the control variables in the estimation model as an open-ended theory of the causal connection between economic growth and another variable. This theory 
PRR

6,3

148

specified that the link between economic growth and another variable cannot be controlled out. That is what Durlauf and Quah (1999) have established before Brock and Durlauf (2001) presented over 90 variables for probable economic growth variables.

However, the prime objective in this research is not to endorse to all theories of economic growth with Sukuk financing, but to examine whether and how the Sukuk financing affects economic growth in the framework of endogenous growth. For this reason, this paper quantified the minimal model for the estimation of Sukuk financing effect on economic growth. Thus, following previous empirical studies related to the topic, this study used the potential macro-economic factors as control variables to omit the issue of bias. Therefore, the general model for investigating the link between Sukuk financing and economic growth in the framework of the endogenous growth model is as the following (Figure. 4):

$$
\mathrm{Y}_{\text {it }}=\alpha_{0}+\alpha_{\mathrm{i}} \mathrm{P}_{\mathrm{it}}+\beta_{\mathrm{i}} \mathrm{X}_{\mathrm{it}}+\xi_{\text {it }} \quad \forall \quad \xi_{\text {it }}=v_{\mathrm{i}}+\mu_{\text {it }}
$$

in which:

$\mathrm{Y}_{\text {it }}$ is the economic growth measure for country $i$ at time $t . P_{i t}$ are the Sukuk financing (Sukuk) for country $i$ at time $t$.

$X_{i t}$ are the variables of macroeconomics (GFCF, Trade and CPI) for country $i$ at time $t . \alpha_{O}$ is a constant term, $\alpha_{i}$ and $\beta_{i}$ are coefficients.

$\xi_{i t}$ is an error term, with $v_{i}$ is the unobserved Sukuk financing effect, and $\mu_{i t}$ the individual error.

Sukuk financing showed a tendency to continue over time, due to obstacles of Sukuk financial markets and macroeconomics shocks on GDP (Echchabi et al., 2016; Malikov, 2017; Smaoui and Nechi, 2017; Al-Raeai et al., 2018; Echchabi et al., 2018; Y1ldırım et al., 2020). Hence, this research used a dynamic condition, including a lagged dependent variable of GDP among the regressors (Arellano, 2003; Croissant and Millo, 2019), the regression of equation (1) improved with lagged GDP as the following:

$$
\mathrm{Y}_{\text {it }}=\alpha_{0}+\partial \mathrm{Y}_{\mathrm{i}, \mathrm{t}-1}+\alpha_{\mathrm{i}} \mathrm{P}_{\mathrm{it}}+\beta_{\mathrm{i}} \mathrm{X}_{\mathrm{it}}+\xi_{\text {it }}
$$

where $\mathrm{Y}_{\mathrm{i}, t-1}$ is the one-quarter lagged of GDP, and $\partial$ is a coefficient of equilibrium speed.

\section{Econometric methodology}

The probable presence of unobserved individual effects is the biggest estimation problem, what makes both fixed or random effects unsuitable for the estimation is the endogeneity,

Figure 4.

Summary of the empirical investigation between Sukuk financing and economic growth in the framework of endogenous growth model

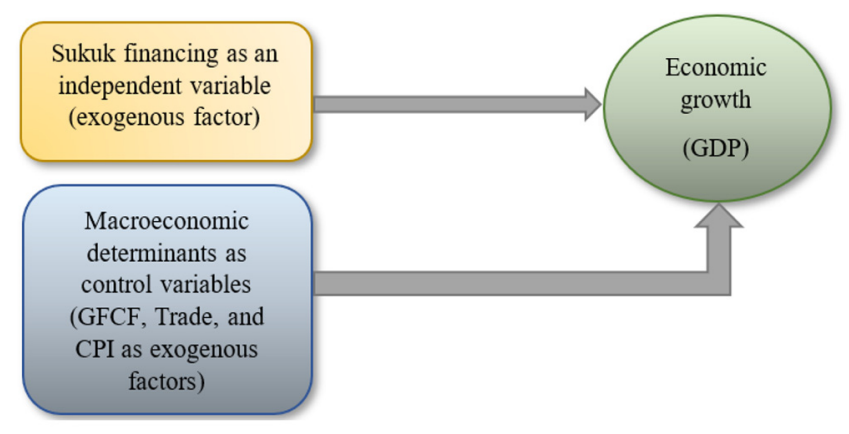

Source: Prepared by authors 
and the correlation between regressors and lagged variables, in which those methods produce bias and mistaken estimation results (Baltagi and Kao, 2001). The first difference panel regression model was estimated by Arellano and Bond (1991), which can eliminate the unnoticed individual effect, wherein the estimation uses all lagged values of the exogenous regressors as an instrument and lagged values of the dependent variable.

Blundell and Bond (1998) determined that the lagged levels of these variables are weak instruments for the regression estimation of differences when the dependent variable and the explanatory variables are resolute across time. For this reason, a new method called the GMM system estimator was developed by Blundell and Bond (1998), which contained within lagged differences and lagged levels as instruments.

Roodman (2009) and Bond (2002) detailed the resolving of the problems correlated to invisible heterogeneity, endogeneity, by the GMM as a system estimation. Thus, this paper applied the one-step system GMM estimator as an alternative solution for the problems of the panel heteroskedasticity, and autocorrelation in the panel with random effects and as an optimal method for the sample of this study (72 observations) because the dynamic panel system GMM estimator is the most appropriate for small and finite samples because it has a lower bias and higher efficiency than all the other estimators analyzed according to Hayakawa (2007) and Soto (2009).

According to Roodman (2009), the GMM estimator model is:

$$
Y=\mathbf{x}^{\prime} \beta+\varepsilon \quad \forall \quad E(\varepsilon \mid \mathbf{w})=0
$$

in which:

$\beta$ is a support vector of coefficients, $y$ and $\varepsilon$ are random variables, $\mathbf{x}=(\mathbf{x} \mathbf{1}, \ldots, \mathbf{x k})$, is a column vector of k regressors, $\mathbf{w}=\left(\mathbf{w}_{\mathbf{1}}, \ldots, \mathbf{w}_{\mathbf{j}}\right)$, is a column vector of $\mathbf{j}$ instruments, $x$ and $w$ can share elements and $\mathbf{j} \geq \mathbf{k}$.

This research used $\mathbf{X}, \mathbf{Y}$ and $\mathbf{W}$ to signify matrices of $\mathrm{N}$ observations for $\mathrm{x}, \mathrm{y}$ and $\mathrm{w}$, and it stated $\mathbf{E}=\mathbf{Y}-\mathbf{X} \boldsymbol{\beta}$.

Given an estimation, $\hat{\beta}$, the experimental residuals are $\hat{\mathbf{E}}=\left(\hat{\mathbf{e}}_{1}, \ldots, \hat{\mathbf{e}}_{\mathrm{N}}\right)^{\prime}$ $=\mathbf{Y}-\mathbf{X} \hat{\beta}$.

This research made no statement at this point about $\mathbf{E}\left(\mathbf{E E}^{\prime} \mid \mathbf{W}\right)=\mathbf{\Omega}$ excepting that it exists.

In the GMM estimator, based on a positive semidefinite quadratic form, one states that magnitude within a generalized metric. $A$ is the matrix for the quadratic form. Then, the metric is:

$$
\left\|\mathbf{E}_{\mathbf{N}}(\mathbf{w} \boldsymbol{\varepsilon})\right\| A=\left\|\frac{1}{N} \mathbf{w}^{\prime} \hat{\mathbf{E}}\right\| \equiv \mathbf{N}\left(\frac{1}{\mathbf{N}} \mathbf{w}^{\prime} \hat{\mathbf{E}}\right)^{\prime} \mathbf{A}\left(\frac{1}{\mathbf{N}} \mathbf{w}^{\prime} \hat{\mathbf{E}}\right)=\frac{1}{\mathbf{N}} \hat{\mathbf{E}}^{\prime} \mathbf{w}_{\mathrm{A}} \mathbf{w}^{\prime} \hat{\mathbf{E}}
$$

This research resolved the minimization problem to derive the indicated GMM estimator, call it $\hat{\boldsymbol{\beta}}_{\mathrm{A}}$ :

$\hat{\boldsymbol{\beta}}_{\mathbf{A}}=\operatorname{argmin} \hat{\mathbf{B}}\left\|\mathbf{w}^{\prime} \hat{\mathbf{E}}\right\| \mathbf{A}$ whose solution is determined by $0=\mathbf{d} /(\mathbf{d} \hat{\boldsymbol{\beta}})\left\|\mathbf{w}^{\prime} \hat{\mathbf{E}}\right\| \mathbf{A}$.

The extension of this derivative with chain law is:

$$
\begin{aligned}
0 & =\frac{\mathrm{d}}{\mathrm{d} \hat{\boldsymbol{\beta}}}\left\|\mathbf{w}^{\prime} \hat{\mathbf{E}} \mathbf{A}\right\|=\frac{\mathrm{d}}{\mathrm{d} \hat{\mathbf{E}}}\left\|\mathbf{w}^{\prime} \hat{\mathbf{E}} \mathbf{A}\right\| \frac{\mathrm{d} \hat{\mathbf{E}}}{\mathrm{d} \hat{\boldsymbol{\beta}}}=\frac{\mathrm{d}}{\mathrm{d} \hat{\mathbf{E}}}\left\{\frac{1}{\mathbf{N}} \hat{\mathbf{E}}^{\prime}\left(\mathbf{w} \mathbf{A} \mathbf{w}^{\prime}\right)\right\} \frac{\mathrm{d}(\mathbf{Y}-\mathbf{X} \hat{\boldsymbol{\beta}})}{\mathrm{d} \hat{\boldsymbol{\beta}}} \\
& =\frac{2}{N} \hat{\mathbf{E}}^{\prime} \mathbf{w} \mathbf{A} \mathbf{w}^{1}(-\mathbf{X})
\end{aligned}
$$

The last phase is to use identity matrix $d \frac{\mathbf{A b}}{d \mathbf{b}}=\mathbf{A}$ and $d \frac{(\mathbf{b} / \mathbf{A b})}{d \mathbf{b}}=2 \mathbf{b} / \mathbf{A}$, where $\boldsymbol{b}$ is a column vector, and $A$ is a symmetric matrix. Falling the factor of $-2 / \mathrm{N}$ and transposing, 
PRR

6,3

150

$$
\begin{aligned}
& 0=\hat{E} W A W^{\prime} X=\left(\mathbf{Y}-\mathbf{X} \hat{\beta}_{\mathrm{A}}\right)^{\prime} W A W^{\prime} X=Y^{\prime} W A W^{\prime} X-\hat{\beta}^{\prime} X^{\prime} W A W^{\prime} X \\
& \Rightarrow X^{\prime} W A W^{\prime} X \hat{\beta}_{\mathrm{A}}=X^{\prime} W A W^{\prime} Y \\
& \Rightarrow \hat{\beta}_{A}=\left(X^{\prime} W A W^{\prime} X\right)^{-1} X^{\prime} W A W^{\prime} Y
\end{aligned}
$$

This is the GMM estimator that is well defined by $A$, linear in $Y$, while $A$ is weights moments (Roodman, 2009).

\section{Results and discussion}

Tables 1 and 2 reported the panel regression estimation outputs with fixed and random effects. To choose the optimal estimation model for the empirical investigation, this paper applied the Hausman test (Baltagi et al., 2003).

Table 3 reported that the null hypothesis is accepted because the $p$-value $(0.0520)$ is bigger than 0.05; thus, according to the Hausman test (Baltagi et al., 2003), the best panel regression model for estimation is the panel with random effects.

To consider that the estimation model of panel regression with random effects is suitable for the empirical investigation according to Wooldridge (2010), three tests were performed for checking the diagnostics, the cross-sectional dependence test of Pesaran (2015), autocorrelation test of Wooldridge (2012) and the Groupwise heteroskedasticity test of Baltagi et al. (2010). Thus, it is indorsed to obtain high insignificant $p$-values (Tables 4, 5 and 6).

Table 4 reported that the null hypothesis can not be rejected with a high insignificant $p$ value $(0.0652>0.05)$; thus, there is no cross-sectional dependence in panel data estimation.

Table 5 reported that the null hypothesis is rejected with a high significant $p$-value $(0.0011<0.01)$. Thus, there is an autocorrelation problem in the panel with random effects regression.

Table 6 reported that the null hypothesis is rejected with a high significant $p$-value $(0.0000<0.01)$; thus, there is a heteroskedasticity problem in the panel with random effects regression.

As the panel regression with random effects is unacceptable due to the existence of autocorrelation and the existence of the heteroskedasticity in panel data, this paper applied the dynamic panel one-step system GMM as an alternative solution for estimation because

\begin{tabular}{|c|c|c|c|c|}
\hline \multicolumn{5}{|c|}{$\begin{array}{l}\text { Dependent variable: GDP observations per group: } \text { min }=24 \\
\text { Number of observations }=72 \text { Number of groups }=3 \text { avg }=24.0 \text { max }=24\end{array}$} \\
\hline Model & \multicolumn{4}{|c|}{$\begin{array}{c}\text { Fixed effects (within regression) } \\
F(4.65)=188.20 \\
\text { Prob }>F=0.0000 \\
\text { Rho }=0.89443321\end{array}$} \\
\hline Var & Coefficient & Standard error & t-statistic & $P>|t|$ \\
\hline Sukuk & 0.8179447 & 0.2122325 & 3.85 & $0.000 * *$ \\
\hline$G F C F$ & 2.531061 & 0.1870501 & 13.53 & $0.000 * *$ \\
\hline Trade & $-3,534.107$ & $7,972.83$ & -0.44 & 0.659 \\
\hline$C P I$ & 413.5167 & 147.3474 & 2.81 & $0.007 * *$ \\
\hline Constant & $-27,331.61$ & $16,499.84$ & -1.66 & 0.102 \\
\hline \multicolumn{5}{|c|}{$\begin{array}{l}\text { Notes: * significant at the } 0.05 \text { level, } * * \text { significant at the } 0.01 \text { level } \\
\text { Source: Panel regression with fixed effects performed by authors using STATA16 software }\end{array}$} \\
\hline
\end{tabular}
of its benefits to omit the problem of autocorrelation and heteroskedasticity in the panel with random effects regression (Blundell and Bond, 1998; Bond, 2002; Roodman, 2009) (Table 7).

Table 1.

Panel regression with fixed effects

Source: Panel regression with fixed effects performed by authors using STATA16 software 
Dependent variable: GDP observations per group: min $=24$

Number of observations $=72$ Number of groups $=3$ avg $=24.0$ max $=24$

Model

Var

Sukuk

GFCF

Trade

CPI

Constant

Notes: * significant at the 0.05 level, ** significant at the 0.01 level

Source: Panel regression with random effects performed by authors using STATA16 software

$$
\text { Wald } X^{2}(4)=36,955.36
$$

Random effects (GLS regression)$$
\text { Prob }>X^{2}=0.0000
$$

$$
\text { Rho }=0
$$

Standard error

0.1465531

0.0682863

$5,088.29$

124.124

$13,949.54$

$z$
6.44
42.76
-1.01
1.87
-1.31

$P>|z|$

$0.000 * *$

$0.000 * *$

0.315

0.062

0.189

Table 2.

Panel regression with random effects
Null hypothesis: difference in coefficients not systematic (panel regression with random effects is suitable)

\begin{tabular}{lc}
\hline$X^{2}$ & Prob $>X^{2}$ \\
5.91 & 0.0520
\end{tabular}

Source: Hausman test performed by authors using STATA16 software
Table 3. Hausman test to choose the optimal panel regression model between fixed and random effects

Null hypothesis: there is cross-sectional independence in panel data

\begin{tabular}{lr}
\hline Z-statistic & $\mathbf{P}>|\boldsymbol{z}|$ \\
0.264 & 0.0652
\end{tabular}

Source: Cross-sectional dependence test performed by authors using STATA16 software

Table 4.

Cross-sectional dependence test

Null hypothesis: no first-order autocorrelation

$\mathrm{F}(1,2)$

868.084

Note: ** significant at the 0.01 level.

Source: Wooldridge test for autocorrelation performed by authors using STATA16 software

\section{Prob $>$ F \\ $0.0011^{* * *}$}

Table 5.

Wooldridge test for autocorrelation in panel data

Table 7 showed that the impact of Sukuk financing on the economic growth is significantly positive on a significance level of $1 \%$ ( $p$-value of Sukuk $=0.000<0.01)$, which indicates that the Sukuk financing is boosting the economic growth in Southeast Asia. Thus, this finding confirmed the validity of the hypothesis that Sukuk financing is positively affecting the economic growth in Southeast Asia. 
PRR

6,3

152

Table 6.

Wald test for groupwise heteroskedasticity in the random effects regression
Concerning the effect of lagged GDP on economic growth (GDP), it is statistically significant and positive on a significance level of $1 \%$ ( $p$-value of lagged GDP $=0.000<0.01$ ), which means that the economic growth in Southeast Asia is adjusted to equilibrium with a speed of $39.90584 \%$.

Regarding the effect of macro-economic control variables on the economic growth, the $\mathrm{GFCF}$, which is a proxy of investments, is affecting the economic growth positively on a significance level of $1 \%$ ( $p$-value of $\mathrm{GFCF}=0.000<0.01)$, which leads to conclude that investments in Southeast Asia are boosting economic growth reliably with the results of Zhang (2001) when he determined that investments boosted economic growth in East Asia, similarly consistent with the findings of Hussin and Saidin (2012) when they conclude that investments in the Association of Southeast Asian Nations (ASEAN) region boosted the economic growth in four countries (Malaysia, Indonesia, Thailand and the Philippines) of the ASEAN region. While the CPI, which is a proxy variable for inflation, is also affecting the economic growth positively on a significance level of $5 \%$ ( $p$-value of $\mathrm{CPI}=0.023<0.05$ ), which indicates that inflation in this situation, is a sign for good economic growth because of the high speed of investments in Southeast Asia, which cause inflation and high levels of living changes costs, high wages and returns in Southeast Asia, this economic phenomenon is reliable with the finding of Xiao (2009) when his findings determined that inflation is positively affecting the economic growth in China because of the high speed of investments that cause inflation. While trade openness (Trade) is insignificant and does not affect the economic growth in Southeast Asia.

Concerning the constant coefficient, it is insignificant, which means that economic growth in this model is not affected by other omitted variables.

\begin{tabular}{lc}
\hline \multicolumn{2}{c}{ Null hypothesis: no groupwise heteroskedasticity } \\
\hline$X^{2}$ & Prob $>X^{2}$ \\
338.7424 & $0.0000^{* * *}$ \\
Note: ** significant at the 0.01 level & \\
Source: Groupwise heteroskedasticity test performed by authors using STATA16 software. & \\
\hline
\end{tabular}

Number of observations $=69$ Number of groups $=3$

Wald $X^{2}(5)=1.28 \mathrm{e}+11$ Prob $>X^{2}=0.000$

Number of instruments $=69$ Observations per group: $\min =23$

$\operatorname{Max}=23$ avg $=23$

\begin{tabular}{lccrc}
\hline Variables & Coefficients & Robust standarderror & $Z$-stat & $P>|z|$ \\
Lagged GDP & 0.3990548 & 0.0141716 & 28.16 & $0.000^{* *}$ \\
Sukuk & 0.5682856 & 0.1204074 & 4.72 & $0.000^{* *}$ \\
GFCF & 1.741779 & 0.0528342 & 32.97 & $0.000^{* *}$ \\
Trade & $-4,402.062$ & $3,462.081$ & -1.27 & 0.204 \\
CPI & 187.7804 & 82.70568 & 2.27 & $0.023^{*}$ \\
Constant & $-14,650.01$ & $11,257.98$ & -1.30 & 0.193
\end{tabular}

Notes: * significant at the 0.05 level, ** significant at the 0.01 level

Source: dynamic panel one-step system GMM performed by authors using STATA16 software 
Concerning the one-step system GMM diagnostics, this empirical investigation performed Arellano-Bond test of serial correlation and Sargan test of over-identifying restrictions, which was established by Arellano and Bond (1991) to test the GMM instruments validity, as it is shown in Table 8. Besides, Arellano and Bond (1991), Blundell and Bond (1998) recommended the Hansen test for the robustness checking that the estimated model is unbiased and robust. Therefore, this paper performed the Hansen test, as it is shown in Table 9 .

According to the Sargan test outputs of over-identifying restrictions in Table 8, the $p$ value is insignificant (probability $>X^{2}=0.267$ ), so the overall validity of instruments is significant, and all instruments as a group are exogenous.

According to the outputs of Arellano-Bond test for the panel serial correlation, the error term of the differenced equation is insignificant because it is not serially correlated at both of the first-order $A R(1)(\operatorname{Pr}>Z=0.267)$ and second-order $A R(2)(\operatorname{Pr}>Z=0.224)$ (Table 8).

According to the Hansen test outputs of robustness in Table 9, the $p$-value is highly insignificant (Prob $>X^{2}=1.000$ ), which indicates that the estimated model of one-step system GMM is robust and unbiased.

As the dynamic panel one-step system GMM in this paper is unbiased and free from the issue of panel serial correlation and the overall instruments in the GMM estimation are valid, the empirical results are robustly correct and accurate. Consequently, the empirical investigation in this study is clean, precise and robustly truthful to work with its results.

\section{Conclusion}

The main objective of this paper is to investigate empirically whether Sukuk financing is boosting the economic growth in Southeast Asia within a new theoretical investigation under the endogenous growth model. The findings indicated that Sukuk financing has a significant effect on the economic growth in Southeast Asia. Unlike what Echchabi et al. (2018) have determined that Sukuk issuance has no significant effect on economic growth, the empirical results of this paper according to the endogenous growth model are reliable with the findings of Yildirım et al. (2020), Al-Raeai et al. (2018), Sari et al. (2018), Malikov (2017), Mitsaliyandito et al. (2017), Smaoui and Nechi (2017) and Khoutem (2014) in

\section{Serial correlation tests}

\begin{tabular}{ccc}
\hline Arellano-Bond test for AR (1) in first differences & $Z=-1.11$ & $\operatorname{Pr}>Z=0.267$ \\
Arellano-Bond test for AR (2) in first differences & $Z=-1.22$ & $\operatorname{Pr}>Z=0.224$ \\
Instruments overall validity test & \\
Sargan test of over-identifying restrictions & $X^{2}(63)=69.54$ & $P r o b>X^{2}=0.267$
\end{tabular}

Source: Dynamic panel one-step system GMM diagnostics performed by authors using STATA 16 software

Table 8.

Diagnostics of dynamic panel onestep system GMM

Robustness test

\begin{tabular}{lll}
\hline Hansen test of robustness & $X^{2}(63)=0.00$ & Prob $>X^{2}=1.000$
\end{tabular}

Source: Dynamic panel one-step system GMM robustness test performed by authors using STATA 16

Table 9.

Robustness test of Hansen 
PRR

6,3

which Sukuk financing or Sukuk markets development has a positive effect on economic growth.

As a conclusion, the Islamic finance industry is playing a major role in boosting economies globally because developed and emerging Muslim and non-Muslim countries have recently started working with Sukuk, one of the easiest ways to finance outside conventional finance system (Yildırım et al., 2020). This paper confirmed that the Islamic financial markets of Sukuk are predicted to be bright in the future as an alternative financial market that empowers the economic growth reliable with the findings of Cevik and Bugan (2018) and Yildirım et al. (2020).

\section{Implications for research and practice}

This study has some implications for research and practice as the ensuing:

- This study aims to examine empirically whether Sukuk financing is boosting the economic growth in Southeast Asia within the endogenous growth model. Thus, the empirical examination in this paper would fill the literature gap by investigating the effect of Sukuk financing on economic growth with a new theoretical context of the endogenous growth model to gain robust information about this link. Therefore, this paper supports financial researchers, decision-makers and policymakers to improve the Sukuk market globally as an alternative financing source for the best contribution to the economic growth.

- In terms of practical implication, this study delivers important evidence for financial researchers, decision-makers, policymakers and associated authorities that Sukuk financing is boosting economic growth, which brings global attention for the significant role of Sukuk financing as an important instrument of Islamic finance on boosting economic growth in Southeast Asia. Thus, the outcome of this paper stimulates financial researchers, decision-makers and policymakers across countries to the necessity of merging Sukuk (Islamic securities) in the financial markets as a major player alongside with conventional securities to finance investments, which empower the economic growth, especially in the Muslim countries that contain a remarkable Islamic population who trust Islamic finance and banking.

\section{References}

Al-Ali, S. (2019), Raising Capital on Sukūk Markets: Structural, Legal and Regulatory Issues, 1st ed., Springer International Publishing; Palgrave Macmillan, available at: (accessed 13 July 2020).

Al-Raeai, A.M., Zainol, Z., Rahim, A.K. B A. and Khilmy, A. (2018), "The role of macroeconomic factors on sukuk market development of Gulf Cooperation Council (GCC) countries", International Journal of Economics and Financial Issues, EconJournals, Vol. 8 No. 3, pp. 333-339.

Arellano, M. (2003), "Panel data econometrics", OUP Catalogue, Oxford University Press, available at: https://econpapers.repec.org/bookchap/oxpobooks/9780199245291.htm (accessed 28 August 2020).

Arellano, M. and Bond, S. (1991), "Some tests of specification for panel data: Monte Carlo evidence and an application to employment equations", The Review of Economic Studies, Vol. 58 No. 2, pp. 277-297.

Baltagi, B.H. and Kao, C. (2001), "Nonstationary panels, cointegration in panels and dynamic panels: a survey", in Baltagi, B.H., Fomby, T.B. and Carter Hill, R. (Eds), Nonstationary Panels, Panel Cointegration, and Dynamic Panels, Vol. 15, Emerald Group Publishing, pp. 7-51. 
Baltagi, B.H., Bresson, G. and Pirotte, A. (2003), "Fixed effects, random effects or Hausman-Taylor?: a pretest estimator", Economics Letters, Vol. 79 No. 3, pp. 361-369.

Baltagi, B.H., Jung, B.C. and Song, S.H. (2010), "Testing for heteroskedasticity and serial correlation in a random effects panel data model", Journal of Econometrics, Vol. 154 No. 2, pp. 122-124.

Bencivenga, V.R. and Smith, B.D. (1991), "Financial intermediation and endogenous growth", The Review of Economic Studies, Vol. 58 No. 2, pp. 195-209.

Blackburn, K. and Hung, V.T.Y. (1998), "A theory of growth, financial development and trade", Economica, Vol. 65 No. 257, pp. 107-124.

Blundell, R. and Bond, S. (1998), "Initial conditions and moment restrictions in dynamic panel data models", Journal of Econometrics, Vol. 87 No. 1, pp. 115-143.

Bond, S.R. (2002), "Dynamic panel data models: a guide to micro data methods and practice", Portuguese Economic Journal, Vol. 1 No. 2, pp. 141-162.

Boukhatem, J. and Moussa, F.B. (2018), "The effect of Islamic banks on GDP growth: some evidence from selected MENA countries", Borsa Istanbul Review, Vol. 18 No. 3, pp. 231-247.

Brock, W.A. and Durlauf, S.N. (2001), "What have we learned from a decade of empirical research on growth? Growth empirics and reality", The World Bank Economic Review, Vol. 15 No. 2, pp. 229-272.

Canlas, D.B. (2020), “(DP 2020-09) is there economic convergence in Asia?”, UPSE Discussion Papers, available at: https://econ.upd.edu.ph/dp/index.php/dp/article/view/1532 (accessed 28 August 2020).

Cevik, E.I. and Bugan, M.F. (2018), "Regime-dependent relation between Islamic and conventional financial markets", Borsa Istanbul Review, Vol. 18 No. 2, pp. 114-121.

Croissant, Y. and Millo, G. (2019), Panel Data Econometrics with R, Wiley Online Library.

Durlauf, S.N. and Quah, D.T. (1999), "The new empirics of economic growth", Handbook of Macroeconomics, Elsevier, Vol. 1, pp. 235-308.

Echchabi, A., Aziz, H.A. and Idriss, U. (2016), "Does sukuk financing promote economic growth? An emphasis on the major issuing countries", Turkish Journal of Islamic Economics, Vol. 3 No. 2, pp. 63-73.

Echchabi, A., Aziz, H.A. and Idriss, U. (2018), "The impact of Sukuk financing on economic growth: the case of GCC countries", International Journal of Financial Services Management, Vol. 9 No. 1, pp. 60-69.

Fanta, A.B. and Makina, D. (2017), "Equity, bonds, institutional debt and economic growth: evidence from South Africa”, South African Journal of Economics, Vol. 85 No. 1, pp. 86-97.

Fink, G., Haiss, P.R. and Hristoforova, S. (2003), Bond Markets and Economic Growth, SSRN Scholarly Paper No. ID 1003763, Social Science Research Network, Rochester, New York, NY, available at: https://doi.org/10.2139/ssrn.1003763

Haini, H. (2019), "Examining the relationship between finance, institutions and economic growth: evidence from the ASEAN economies", Economic Change and Restructuring, Vol. 53 No. 4, doi: 10.1007/s10644-019-09257-5.

Hassan, M.K., Sanchez, B. and Yu, J.S. (2011), "Financial development and economic growth: new evidence from panel data", The Quarterly Review of Economics and Finance, Vol. 51 No. 1, pp. 88-104.

Hayakawa, K. (2007), "Small sample bias properties of the system GMM estimator in dynamic panel data models", Economics Letters, Vol. 95 No. 1, pp. 32-38.

Hussin, F. and Saidin, N. (2012), "Economic growth in ASEAN-4 countries: a panel data analysis", International Journal of Economics and Finance, Vol. 4 No. 9.

IIFM Sukuk Report 2019 8th Edition (2020), "International Islamic financial market", available at: www.iifm.net/sukuk-reports/ (accessed 14 July 2020). 
PRR

6,3

Islamic Financial Services Board (2020), "Islamic Financial Services Board (IFSB)", available at: www. ifsb.org/psifi_06.php (accessed 11 February 2020).

Jhingan, M.L. (2011), The Economics of Development and Planning, Vrinda Publications, Delhi.

Kapingura, F. and Makhetha-Kosi, P. (2014), "The causal relationship between the bond market development and economic growth in Africa: case study of South Africa”, Mediterranean Journal of Social Sciences, Vol. 5 No. 3, p. 126.

Kassim, S. (2016), "Islamic finance and economic growth: the Malaysian experience", Global Finance Journal, Vol. 30, pp. 66-76.

Khoutem, D.B.J. (2014), "Islamic banks-Sukuk markets relationships and economic development: the case of the Tunisian post-revolution economy", Journal of Islamic Accounting and Business Research, Vol. 5 No. 1, pp. 47-60.

King, R.G. and Levine, R. (1993), "Finance and growth: Schumpeter might be right", The Quarterly Journal of Economics, Vol. 108 No. 3, pp. 717-737.

Lahsasna, A., Hassan, M.K. and Ahmad, R. (2018), Forward Lease Sukuk in Islamic Capital Markets: Structure and Governing Rules, 1st ed., Springer International Publishing, Palgrave Macmillan, available at: (accessed 3 April 2020).

Ledhem, M.A. and Mekidiche, M. (2020), "Economic growth and financial performance of Islamic banks: a CAMELS approach”, Islamic Economic Studies, Vol. 28 No. 1, pp. 47-62.

Levine, R. and Zervos, S. (1998), "Stock markets, banks, and economic growth", American Economic Review, Vol. 88 No. 3, pp. 537-558.

McKinnon, R.I. (1973), Money and Capital in Economic Development, Brookings Institution Press.

Malikov, A. (2017), "How do sovereign sukuk impact on the economic growth of developing countries? An analysis of the infrastructure sector", in Efendić, V., Hadžić, F. and Izhar, H. (Eds), Critical Issues and Challenges in Islamic Economics and Finance Development, Springer International Publishing, Cham, pp. 1-37.

Mitsaliyandito, R.Q., Arundina, T. and Kasri, R.A. (2017), "Impact of Sukuk market development on Indonesian economic growth", International Journal of Applied Business and Economic Research, Serials Publications, Vol. 15 No. 24, pp. 537-549.

Pesaran, M.H. (2015), "Testing weak cross-sectional dependence in large panels”, Econometric Reviews, Vol. 34 No. 6/10, pp. 1089-1117.

Pradhan, R.P., Zaki, D.B., Maradana, R.P., Dash, S., Jayakumar, M. and Chatterjee, D. (2015), "Bond market development and economic growth: the G-20 experience", Tékhne, Vol. 13 No. 1, pp. 51-65.

Rajan, R.G. and Zingales, L. (1996), Financial Dependence and Growth, National bureau of economic research.

Reuters, T. (2020), "State of the global Islamic economy report 2019/20", Thomson Reuters, DinarStandard, available at: www.salaamgateway.com/SGIE19-20 (accessed 3 January 2020).

Romer, D. (2011), "Endogenous growth”, Advanced Macroeconomics, 4th ed., McGraw-Hill, New York, NY, pp. 101-149.

Roodman, D. (2009), "How to do xtabond2: an introduction to difference and system GMM in stata", The Stata Journal: Promoting Communications on Statistics and Stata, Vol. 9 No. 1, pp. 86-136.

Saint-Paul, G. (1992), "Technological choice, financial markets and economic development”, European Economic Review, Vol. 36 No. 4, pp. 763-781.

Sari, N., Ak, S. and Widiyanti, M. (2018), "The impact of Islamic capital market development on economic growth: the case of Indonesia", Journal of Smart Economic Growth, Vol. 3 No. 2, pp. 21-30.

Schumpeter, J.A. Redvers, O. (1934), "Theorie Der Wirtschaftlichen Entwicklung. The theory of economic development. An inquiry into profits, capital, credit, interest, and the business cycle. . . translated. . . by redvers opie". 
Setyawati, I., Suroso, S., Suryanto, T. and Nurjannah, D.S. (2017), "Does financial performance of Islamic banking is better? Panel data estimation”, European Research Studies, Vol. 20 No. 2, p. 592.

Shaw, E.S. (1973), Financial Deepening in Economic Development, No., Oxford University Press, New York, NY.

Smaoui, H. and Nechi, S. (2017), "Does sukuk market development spur economic growth?”, Research in International Business and Finance, Vol. 41, pp. 136-147.

Soto, M. (2009), "System GMM estimation with a small sample", No. 395, Working Papers, Barcelona Graduate School of Economics, available at: https://ideas.repec.org/p/bge/wpaper/395.html (accessed 2 March 2020).

Thumrongvit, P., Kim, Y. and Pyun, C.S. (2013), "Linking the missing market: the effect of bond markets on economic growth", International Review of Economics and Finance, Vol. 27, pp. 529-541.

Wooldridge, J. (2012), "Panel data models with heterogeneity and endogeneity", Institute for Fiscal Studies.

Wooldridge, J.M. (2010), Econometric Analysis of Cross Section and Panel Data, 2nd ed., The MIT Press, available at: (accessed 22 August 2020).

Xiao, J. (2009), "The relationship between inflation and economic growth of China: empirical study from 1978 to 2007”, available at: http://lup.lub.lu.se/student-papers/record/1502490 (accessed 17 July 2020).

Yıldırım, S., Yıldırım, D.C. and Diboglu, P. (2020), "Does Sukuk market development promote economic growth?", PSU Research Review, doi: 10.1108/PRR-03-2020-0011.

Zhang, K.H. (2001), "Does foreign direct investment promote economic growth? Evidence from East Asia and Latin America", Contemporary Economic Policy, Vol. 19 No. 2, pp. 175-185.

\section{Corresponding author}

Mohammed Ayoub Ledhem can be contacted at: ledhem.edu@gmail.com

For instructions on how to order reprints of this article, please visit our website: 